\title{
EFEK HETEROSIS BERBAGAI PENAMPILAN TIKTOK JANTAN DAN BETINA
}

\section{THE HETEROSIS EFFECT OF MULTIPLE APPEARANCE OF MALE AND FEMALE MULE DUCKS}

\author{
Barep Sutiyono*, Soedarsono, Seno Johari, dan Yon Supri Ondho \\ Fakultas Peternakan, Universitas Diponegoro, Semarang
}

\begin{abstract}
INTISARI
Penelitian bertujuan untuk mengetahui efek heterosis dari tiktok jantan dan betina. Materi yang digunakan itik 24 jantan, 12 betina, entok 12 jantan, 23 betina dan tiktok 24 jantan, 24 betina. Variabel yang diukur adalah berat badan, karkas, non karkas, jerohan, telur, panjang badan, leher, tulang dada dan lingkar dada. Analisis data yang digunakan adalah uji rata-rata menurut metode General Linier Model (GLM), dari program Stastitical Analysis Sistem (SAS) dan perhitungan efek heterosis secara statistik deskriptif. Hasil penelitian menunjukkan bahwa efek heterosis ukuran tubuh tiktok jantan lebih banyak positif, $0,69-8,81 \%$, sebagian kecil negatif $-2,23$ sampai $-2,74 \%$. Pada tiktok betina semua efek heterosis negatif yaitu $-0,03$ sampai $-45,36 \%$. Disimpulkan bahwa efek heterosis tiktok jantan lebih banyak positif sedang pada betina semuanya negatif.
\end{abstract}

(Kata kunci: Persilangan, Spesies, Tiktok, Ukuran tubuh, Efek heterosis)

\section{ABSTRACT}

This study aims to determine the heterosis effect of mule ducks. The material used 24 males ducks, 12 females, muscovy 12 males, 23 females and 24 males mule duck, 24 female. Variables measured were the body weight, carcass, non carcass, giblets and egg, length of body, neck, chest bones and body circumference. Analysis of test data used was the average according to the method of the General Linear Model (GLM), from Stastitical Analysis Sistem (SAS) and calculation of descriptive statistical heterosis effect. Results showed that heterosis effects of male body meansure mule duck more positive, from 0.69 to $8.81 \%$, a fraction of negative -2.23 to $-2.74 \%$. At mule ducks females all negative heterosis effect is -0.03 to $-45.36 \%$. Conclusion heterosis effect males mule ducks were more positive in females were all negative.

(Keywords: Crossing, Species, Mule duck, Body meansure, Heterosis effect)

\section{Pendahuluan}

Dalam ilmu pemuliaan ternak istilah persilangan (hybrid) ada tiga macam yaitu silang dalam (inbreeding), silang luar (out breeding) dan silang antar spesies (intercrossing). Persilangan antar spesies, antara itik jantan dengan entok betina banyak terjadi secara alami dipeternakan rakyat. Persilangan antar spesies akan mendapatkan keturunan atau intercrosbred yang mengontrol efek heterosis dari kombinasi gen yang bermanfaat dari kedua spesies (He'rault et al., 2008) atau kombinasi gen dari kedua spesies yang cocok dengan lingkungan intercrosbred dalam mendukung penampilan suatu karakter. Menurut Cassady et al. (2002), dalam persilangan antar spesies akan muncul heterosis dari suatu karakter akibat dari

\footnotetext{
* Korespondensi (corresponding author):

Telp. +628156567539

E-mail: barep.sutiyono@yahoo.com
}

hetero-genetik. Hetero-genetik tersebut adalah pertemuan antara berbagai gen yang mengontrol bermacam-macam sifat dalam menumbuhkan karakter, baik karakter kualitatif maupun kuantitatif. Sifat gen dominan, over dominan dan epistasis merupakan sifat genetik non aditif yang lebih nampak pengaruhnya terhadap timbulnya efek heterosis. Efek heterosis tersebut nilainya ada yang positif, ada pula yang negatif. Efek heterosis positif yaitu rata-rata penampilan suatu karakter keturunan hasil persilangan melebihi rata-rata penampilan kedua tetuanya, sedang efek heterosis negatif adalah rata-rata penampilan suatu karakter keturunan hasil persilangan yang lebih rendah dari rata-rata penampilan kedua tetuanya. Penampilan yang berhubungan dengan produksi pada umumnya heterosis positif, sedang penampilan reproduksi pada umumnya heterosis efek negatif (Cassady et al., 2002). Dalam usaha untuk memperbaiki aktivitas diastatik gen yang memunculkan efek heterosis yang dikehendaki, perlu dilakukan seleksi 
secara ketat dan berulang pada kedua tetuanya terhadap sifat yang akan digabungkan, untuk memperoleh kedua tetua yang betul-betul baik dalam memunculkan heterosis yang baik pula (Cassady et al., 2002; Wawro et al., 2004; Baeza, 2006).

Menurut Marie-Etancelin et al. (2008), menyilangkan itik dengan entok bertujuan untuk mendapatkan itik persilangan yang baik, dengan memanfaatkan heritabilitas dan korelasi genetik yang berhubungan erat dengan produksi. Tiktok di dunia peternakan dikenal ternak yang tidak dapat berkembang biak atau steril, maka tiktok di Indonesia hanya sebagai ternak final-stock yaitu dimanfaatkan sebagai itik penghasil daging. Di Eropa terutama di Perancis tiktok yang dikenal dengan nama mule duck dimanfaatkan sebagai penghasil fatty-liver atau lemak hati (Setiawan, 2001; He'rault et al., 2008; Marie-Etancelin et al., 2008).

Hyankova et al. (2002) menyatakan, efek heterosis bobot badan pada puyuh tidak konstan selama pertumbuhan setelah menetas dari setiap persilangan dan umumnya besarnya efek heterosis tersebut akan mempengaruhi bobot telur yang dihasilkan. Persilangan antara itik Pekin dengan Bronw-Tsaiya menurut Velez et al. (1996) menghasilkan crosbred, yang mempunyai efek genetik produksi dan kesuburan telur dari Bronw-Tsaiya, dan kesuburan induk dari genetik Pekin. Persilangan tersebut mempunyai efek heterosis 34\% dan $10 \%$ pada berat badan umur 30 dan 52 minggu, serta efek heterosis $8,8 \%$ untuk berat telur dan 5,4\% untuk kesuburan telur. Suryana (2008) menyatakan bahwa daging tiktok berkadar protein relatif sama dengan daging entok, tetapi kadar lemak lebih rendah dan persentase karkas lebih tinggi yaitu mencapai $63,23 \%$. Tiktok pada umur 8 minggu yang dipelihara secara sederhana dan diberi pakan seadanya dapat mencapai berat hidup 1,22-1,92 kg/ekor (Setioko, 2003). Menurut Sunari et al. (2001), berat potong tiktok umur 6 dan 10 minggu masing-masing $1.230,4 \pm 310,8 \mathrm{~g}$ dan $1.920,3 \pm 164,9$ $\mathrm{g}$, untuk yang jantan, sedangkan untuk tiktok betina $1.080,0 \pm 107,5 \mathrm{~g}$ dan $1.911,8 \pm 102,5 \mathrm{~g}$. Selanjutnya Sunari et al. (2001) menerangkan bahwa perbandingan karkas, bukan karkas pangan, sampah yang tidak dibedakan berdasarkan jenis kelamin untuk umur 6 minggu masing-masing, 57,4 $\pm 34 \%$, $16,3 \pm 2,1 \%$ dan $27,8 \pm 5,3 \%$, sedang pada umur 10 minggu, $63,2 \pm 1,1 \%, 14,6 \pm 1,1 \%$ dan $20,4 \pm 1,0 \%$. Dalam usaha mendapatkan kualitas dan kuantitas daging tiktok yang baik, lebih efisien apabila dilakukan seleksi pada entok sebagai tetua tiktok (Chartrin et al., 2006).

\section{Materi dan Metode}

Penelitian dilakukan selama satu tahun dua bulan yaitu dari bulan Januari 2010 sampai Februari 2011, di Laboratorium Pemuliaan dan Reproduksi Ternak Fakultas Peternakan Universitas Diponegoro Semarang. Penelitian menggunakan materi 24 itik dewasa jantan dan 12 betina, 12 entok dewasa jantan dan 23 betina dan 24 tiktok dewasa jantan dan 24 betina. Itik jantan dan entok betina dipasangkan dengan rasio 2 itik jantan 2 entok betina dan 4 itik jantan dengan 3 entok betina untuk menghasilkan tiktok yang digunakan sebagai materi penelitian. Kandang yang digunakan mempunyai luas $4,5 \mathrm{~m}^{2}\left(3 \times 1,5 \mathrm{~m}^{2}\right)$ dan $6 \mathrm{~m}^{2}\left(3 \times 2 \mathrm{~m}^{2}\right)$. Kandang tersebut berlantai plasteran semen yang ditutupi liter dari sekam setebal $\pm 15 \mathrm{~cm}$ dengan pagar dari ram bambu setinggi $1,5 \mathrm{~m}$.

Ransum yang diberikan berupa campuran bekatul, jagung giling dan tepung ikan dengan perbandingan $2: 1: 1$. Ransum diberikan sebanyak 120 g per ekor per hari yang diberikan pukul 07.0008.00 dan pukul 16.00-17.00 WIB. Ransum tersebut mempunyai kandungan nutrisi, protein kasar (PK) $17,10 \%$ dan metabolism energy (ME) 3417,50 $\mathrm{kcal} / \mathrm{kg}$ ransum. Ransum-ransum tersebut diberi vitamin mineral premix $250 \mathrm{~g}$ per $100 \mathrm{~kg}$ ransum. Data hidup maupun data setelah dipotong itik dan entok dikoleksi lebih dahulu. Data Tiktok diukur setelah tiktok yang dihasilkan mencapai dewasa tubuh. Pengambilan data dilakukan waktu materi masih hidup dan sudah dipotong. Materi betina dipotong pada waktu periode bertelur pertama berhenti.

\section{Variabel yang diukur pada waktu materi masih hidup}

Variabel yang diukur pada waktu materi masih hidup antara lain berat hidup, panjang badan, lingkar badan, panjang leher, panjang tulang dada, dan berat telur. Metode pengukuran panjang badan, lingkar dada, panjang leher, panjang tulang dada dapat dilihat pada Gambar 1.

Berat hidup (kg) ditimbang pada waktu pagi hari sebelum diberi pakan. Panjang badan $(\mathrm{cm})$ diukur dari ujung tulang torakalis pertama sampai ujung muka tulang ekor pertama. Lingkar badan (cm) diukur melingkar pada bagian dada masuk dan menempel pangkal sayap. Panjang leher $(\mathrm{cm})$ diukur dari persendian tulang tengkorak dengan tulang atlas sampai tulang torakalis pertama. Panjang tulang dada $(\mathrm{cm})$ diukur mulai panjang tulang dada bagian tengah dari ujung depan sampai ujung belakang. Berat telur (g) ditimbang setelah telur tersebut dibersihkan dari kotoran yang menempel pada kerabangnya. 


\section{Variabel yang diukur setelah materi dipotong}

Variabel yang diukur setelah materi dipotong antara lain berat karkas, non karkas, dan jerohan. Bobot karkas $(\mathrm{kg})$ yaitu bobot bersih yang dikurangi berat bagian bukan karkas (kepala, kaki, darah, bulu, seluruh organ dalam dada dan isi perut). Bobot non karkas yang dapat dimakan (g) yaitu bobot bagian tubuh yang dapat/layak dimakan selain karkas yaitu kepala, leher, kaki dan sayap. Bobot jerohan (g) yaitu bobot organ dalam dada dan

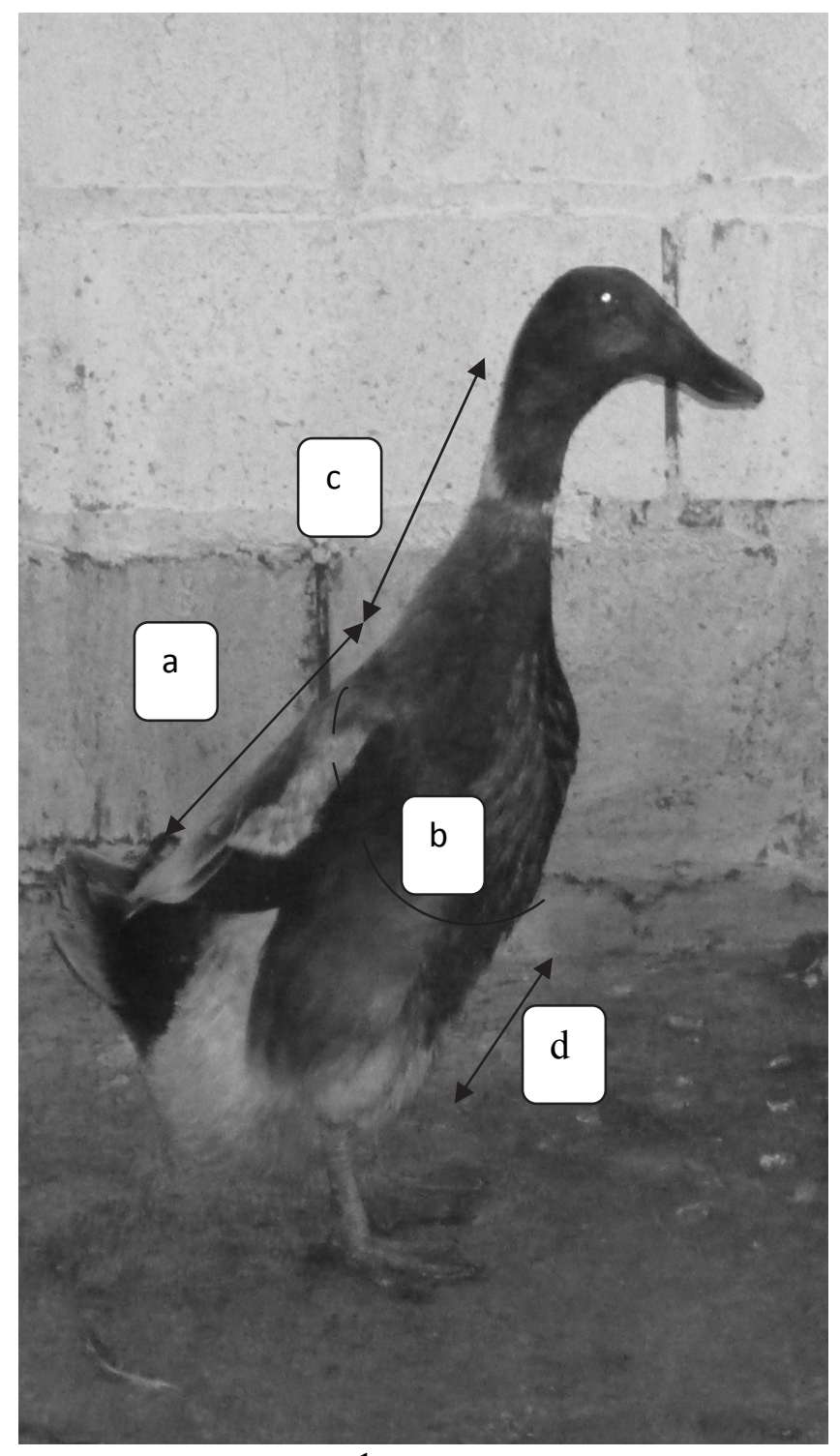

1 perut (empela, hati dan usus) yang telah dibersihkan.

\section{Analisis data}

Data kuantitatif dari itik, entok dan tiktok yang diukur untuk rata-ratanya menggunakan metode General Linier Model (GLM) dengan bantuan program Stastitical Analysis Sistem (SAS) yang merupakan uji $t$ 'student untuk menguji ratarata lebih dari dua kelompok, sedangkan dalam analisis efek heterosis digunakan statistik deskriptif.

Gambar 1. Metode pengukuran bagian badan itik, entok dan tiktok (1: gambar itik hidup, 2: gambar kerangka itik sebagai petunjuk batas-batas pengukuran tubuh) (the measurement methods of duck, muscovy and mule duck. 1. picture of live duck, 2. picture squelette of duck for clarity frame as the limits of body measurement).

Keterangan:

a. Panjang badan (body length)

c. Panjang leher (neck length)

$b$. Lingkar dada (heart girth)

$d$. Panjang tulang dada (chest bones length) 


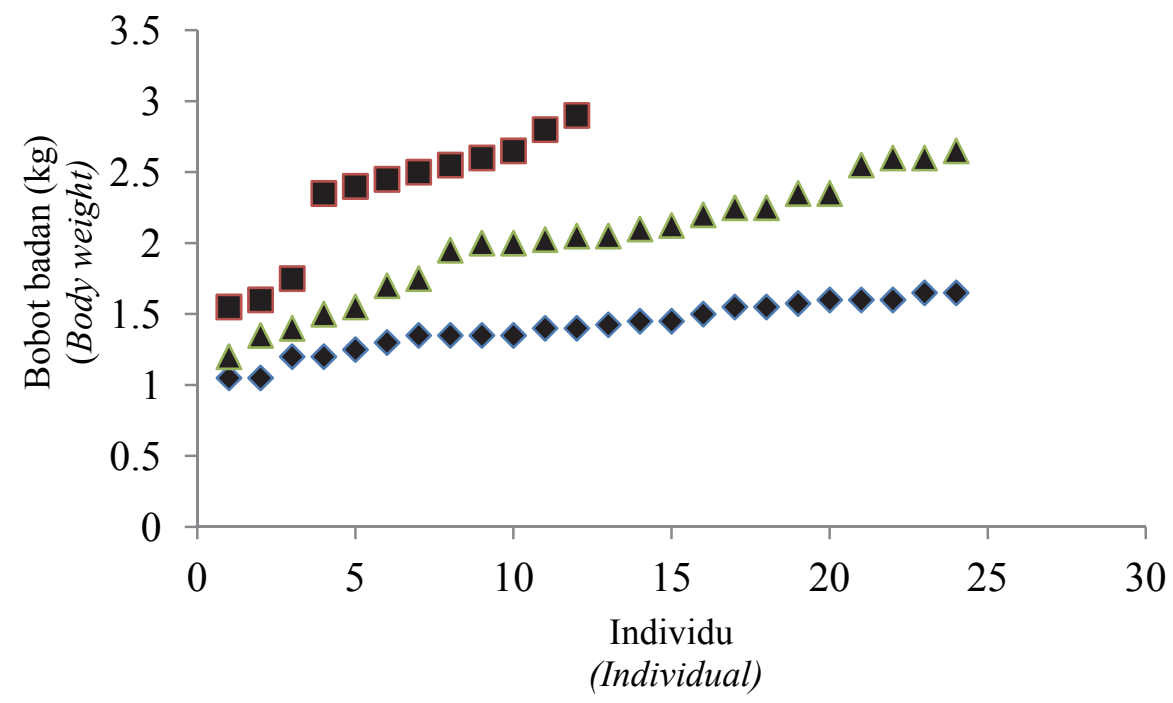

$\bullet$ Itik $\mathbf{\square}$ Entok $\Delta$ Tiktok

Gambar 2. Sebaran bobot badan itik, entok dan tiktok jantan dari bobot terendah sampai bobot tertinggi (the body weight males duck, muscovy and mule duck from lowest to the highest weight).

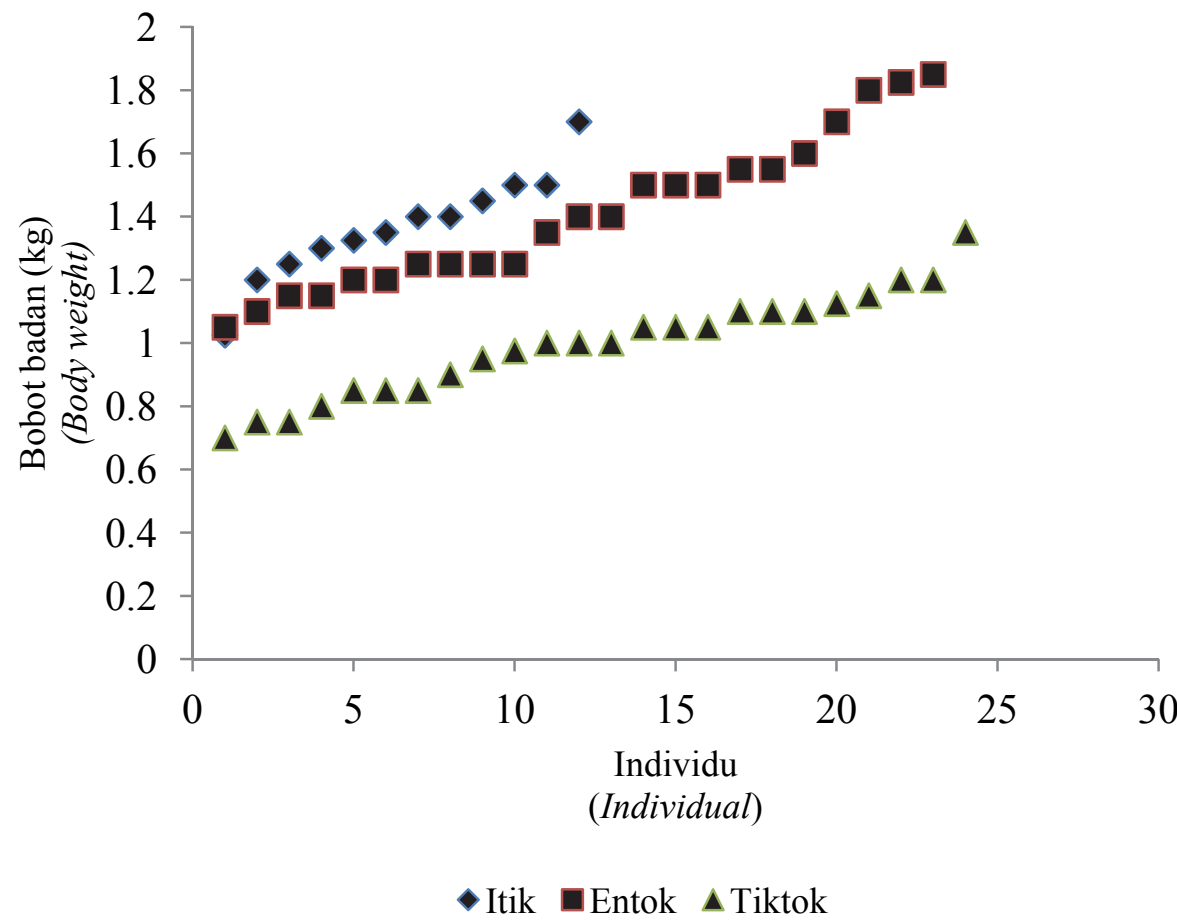

Gambar 3. Bobot badan itik, entok dan tiktok betina dari bobot terendah sampai yang tertinggi (the body weight females duck, muscovy and mule duck from lowest to the highest weight).

\section{Hasil dan Pembahasan}

\section{Penampilan itik, entok, dan tiktok jantan}

Persilangan ternak meningkatkan individu ternak heterosigot, dan akan menyebabkan munculnya efek heterosis. Efek heterosis adalah perbedaan rata-rata penampilan dari keturunan hasil persilangan dengan rata-rata penampilan kedua tetua. Efek heterosis terjadi akibat adanya penggabungan genetik yang mempunyai perbedaan kekuatan dari kedua tetua, terjadi penyimpangan penampilan keturunan yang menyimpang dari penampilan kedua tetua. Rata-rata berbagai penampilan itik, entok, dan tiktok jantan disajikan pada Tabel 1.

Berat badan merupakan ukuran tubuh utama yang mempunyai nilai ekonomis tinggi. Berdasarkan uji statistik bobot badan entok jantan lebih berat $(\mathrm{P}<0,05)$ dari berat tiktok jantan, dan berat badan tiktok jantan lebih berat $(\mathrm{P}<0,05)$ dari berat itik. Pada Gambar 2 kurva berat badan tiktok jantan dari 
yang teringan sampai terberat, selalu berada di antara berat badan entok dengan itik. Keadaan tersebut didukung oleh berat jerohan (BJ) entok, lebih berat $(\mathrm{P}<0,05)$ dari tiktok dan ukuran tubuh yang lain antara entok dan tiktok tidak berbeda nyata. Disamping itu juga disebabkan karena panjang badan (PB), lingkar dada (LD), bobot non karkas (BNK) dan (BJ) dari tiktok lebih panjang $(\mathrm{P}<0,05 \%)$ dari itik, sedangkan efek heterosis 6 penampilan ukuran tubuh tiktok jantan, berat badan (BB), PB, LD, PD, berat karkas (BK) dan BJ menunjukkan angka yang positif, berkisar antara 0,07 sampai $8,81 \%$. PL dan BNK menunjukkan efek heterosis yang negatif dengan kisaran -2,23 sampai $-2,74 \%$. Keadaan efek heterosis ukuran tubuh tiktok jantan tersebut menunjukkan bahwa gen-gen dari itik dan entok yang menyusun genom tiktok dalam penampilan setiap karakter ukuran tubuh sangat bervariasi. Efek heterosis terendah berat non karkas $-2,74 \%$ dan tertinggi adalah berat badan $8,81 \%$.

\section{Penampilan itik, entok, dan tiktok betina}

Penampilan ternak betina sangat berbeda dengan penampilan ternak jantan, demikian juga pada itik, entok dan tiktok. Ternak jantan lebih tinggi menghasilkan hormon testosteron. Menurut Waterman dan Keeney (1992), testosteron mempengaruhi perkembangan individu jantan sehingga penampilannya dapat dibedakan dengan penampilan betina. Penampilan ukuran tubuh, produksi telur dari itik, entok dan tiktok tersaji pada Tabel 2.

Berdasarkan analisis statistik menunjukkan bahwa berat badan itik, entok dan tiktok betina tidak berbeda nyata, tetapi LD entok dengan tiktok lebih panjang dan berbeda nyata $(\mathrm{P}<0,05)$ dari $\mathrm{LD}$ itik. Panjang leher, BNK dan BJ itik betina lebih panjang dan lebih berat serta berbeda nyata $(\mathrm{P}<0,05)$ dari entok maupun tiktok betina, sedangkan berat telur, secara berurutan telur entok lebih berat dan berbeda nyata $(\mathrm{P}<0,05)$ dari telur itik dan telur itik lebih besar dan berbeda nyata $(\mathrm{P}<0,05)$ dengan telur tiktok.

Efek heterosis dari 9 penampilan tiktok betina, semuanya negatif. Besarnya heterosis tersebut berkisar dari $-0,03$ sampai $-45,36 \%$. Heterosis yang terkecil adalah berat telur dan yang terbesar lingkar dada. Pada Gambar 3 menunjukkan bahwa berat badan tiktok dari berat yang teringan sampai yang terberat selalu berada di bawah berat badan itik maupun entok. Keadaan tersebut mencerminkan bahwa efek heterosis semua ukuran tubuh yang diamati negatif, sebab berat badan, sangat dipengaruhi oleh ukuran-ukuran tubuh tersebut.
Berdasarkan penampilan ukuran tubuh dan heterosis efek tiktok jantan maupun betina, persilangan antara itik jantan dengan entok betina tidak memberikan hasil yang menggembirakan. Pada umumnya peternak melakukan persilangan untuk menghasilkan efek heterosis yang tinggi, dan untuk mempertahankan efek heterosis tersebut, keturunannya disilangkan secara bolak-balik (visuversa), dengan bangsa pejantan kemudian dengan bangsa betinanya. Berat badan tiktok jantan mempunyai heterosis positif, artinya berat badan tiktok jantan lebih berat dibandingkan rata-rata dari berat badan entok jantan dan itik jantan. Disamping itu tiktok jantan kemungkinan menghasilkan daging lebih banyak sebab mempunyai badan lebih panjang yaitu rata-rata $23,62 \mathrm{~cm}$ dibandingkan entok 22,71 $\mathrm{cm}$ dan itik $20,83 \mathrm{~cm}$. Tiktok betina dari segi ukuran tubuh yang berhubungan dengan produksi karkas maupun produksi telur tidak ada harapan yang dapat melebihi itik maupun entok karena semua heterosisnya negatif.

Efek heterosis pada tiktok merupakan penampilan dari adanya perpaduan dari alel-alel gen yang berasal dari itik dan entok, tetapi bekerja bersama-sama untuk memunculkan suatu karakter. Menurut Xu dan Zhu (1999), heterosis terjadi akibat adanya interaksi dari pertemuan diantara gen-gen aditif maupun perpaduan aktivitas gen pada suatu lingkungan yang mendukung atau lingkungan yang cocok. Tiktok merupakan hasil persilangan antara itik dengan entok, oleh sebab itu kombinasi gen dari itik dan entok akan memunculkan heterosis. Efek heterosis yang nilai ekonomis tinggi adalah bertambahnya produksi dan membaiknya reproduksi dari generasi yang didapat. Efek heterosis suatu karakter dapat juga negatif, yang disebabkan oleh perpaduan gen yang menimbulkan suatu sifat menjadi lebih rendah dari rata-rata penampilan kedua tetuanya. Efek heterosis yang negatif pada persilangan antar spesies lebih tampak pada karakter reproduksi (Cassady et al., 2002). Besarnya efek heterosis kualitas daging sangat ditentukan oleh kombinasi antara genetik kedua tetuanya yang didukung oleh usia dan nutrisi pakan yang diberikan (Baeza, 2006). Efek heterosis yang berasal dari efek genetik non aditif (dominan, over dominan, epistasis) yang selalu lebih nampak (Wawro et al., 2004). Empat jenis itik yang mempunyai urutan berat badan pada umur 10 minggu, dari terberat yaitu itik cherry-valley, entok, jinding dan sumuma oleh Wen-lin et al. (2009) disilangkan antara entok dengan itik cherry-valley, jinding dan sumuma. Tiktok yang dihasilkan mempunyai efek heterosis berat badan pada umur 10 minggu masingmasing $30,33,12,80$, dan $22,04 \%$. 


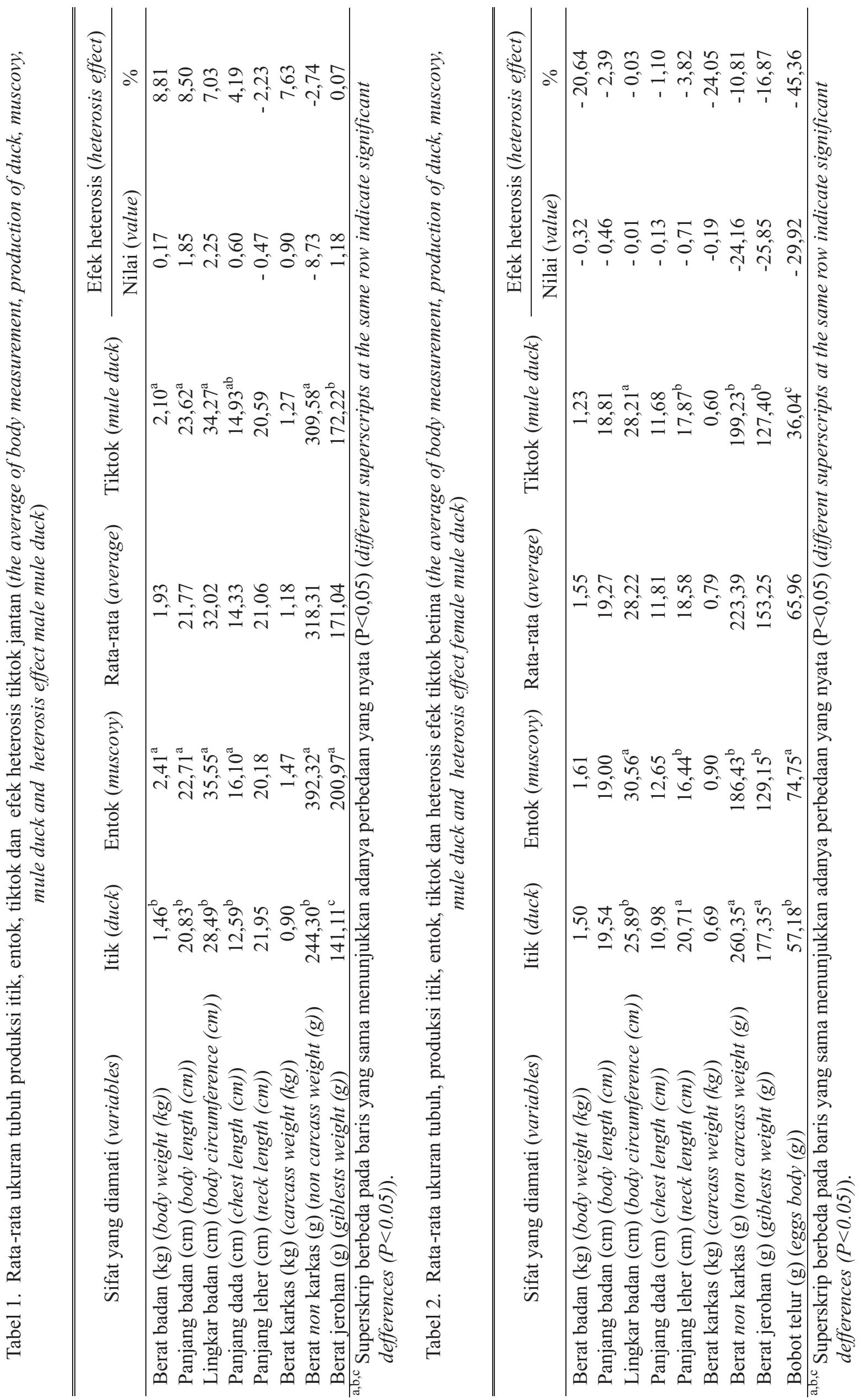




\section{Kesimpulan}

Pada tiktok jantan, efek heterosis berat badan, panjang badan lingkar dada, panjang dada berat karkas dan berat jerohan, bernilai positif, sedang panjang leher dan berat non karkas, bernilai negatif. Pada tiktok betina, efek heterosis semua penampilan dari sifat yang diamati bernilai negatif.

\section{Ucapan Terima kasih}

Penelitian ini adalah sebagian dari hasil penelitian yang dibiayai Program Penelitian Hibah Doktor tahun anggaran 2010 dengan kontrak nomor: 488/SP2M/VI/2010. Kami mengucapkan terima kasih kepada DIKTI dan Rektor Universitas Diponegoro atas bantuan dan kepercayaannya.

\section{Daftar Pustaka}

Baeza, E. 2006. Effects of genotype, age and nutrition on intramuscular lipids and meat quality. Symp. COA/IRA Sci. Coop. Agric. Tainan (Taiwan, R.O.C). November 7-10.

Cassady, P.J., L.D. Yung, and K.A. Leymaster. 2002. Heterosis and rekombinant effects on pig reproductive traits. J. Anim. Sci. 20(9): 2303-2315.

Chartrin, P., K. Meteau, H. Juin, M.D. Bernadet, G. Guy, C. Larzul, H. Remignon, J. Mourot, M.J. Duclos, and E. Baeza. 2006. Effects of intramuscular fat levels on sensory characteristics of duck breast meat. Poult. Sci. 85: 914-922.

He'rault, F., E. Robert, and C. Diot. 2008. Quantitative real-time PCR primer design, DNA amplification and sequence analysis from 22 genes mainly associated with lipid metabolism in Pekin (Anas platyrhynchos) and Muscovy (Cairina moschata) ducks. INRA, UMR598, Anim. Genet. 39(3): 325327.

Hyankova, L., L. Dedkova, H. Knizetova, and J. Hort. 2002. Heterosis in body weight related to growth performance of parental lines of japanese quail and to heterosis in lay. $\mathrm{Br}$. Poult Sci. 43(4): 508-517.
Marie-Etancelin, H. Chapuis, J.M. Brun, C. Larzul, M.M. Mialon-Richard, and R. Rouvier. 2008. Genetics and selection of mule ducks in France. World Poult. Sci. J. 64: 187-208.

Setiawan, I. 2001. Performa itik mandalung sebagai penghasil fatty liver berdasarkan umur dan intensitas force-feeding. Lokakarya Nasional Unggas Air "Pengembangan Agribisnis Unggas Air Sebagai Peluang Bisnis Baru". Dies Natalis IPB Ke 38: 22-24.

Setioko, A.R. 2003. Keragaman itik serati sebagai itik pedaging dan permasalahannya. Wartazoa 3(1): 14-21.

Sunari, Rukmiasih, dan Hardjosworo. 2001. Persentase produksi bagian pangan dan non pangan itik mandalung dari berbagai umur. Lokakarya Nasional Unggas Air "Pengembangan Agribisnis Unggas Air Sebagai Peluang Bisnis Baru". Dies Natalis IPB Ke 38: 59-62.

Suryana. 2008. Peluang dan kendala pengembangan itik serati sebagai penghasil daging. J. Litbang Pertanian. 27(1): 24-30.

Velez, A., J.M. Brun, and R. Rouvier. 1996. Crossbreeding effects on reproductive traits in two strains of duck (Anas platyrhynchos): Brown Tsaiya and Pekin. Br. Poult. Sci. 37(3): 571-577.

Waterman, M.R. and D.S. Keeney. 1992. Genes involved in androgen biosynthesis and the mallard phenotype. Horm. Res. 1992. 38: 217-221.

Wawro, K., E.W. Wawro, K. Kleczek, and W. Brzozowski. 2004. Slaughter value and meat quality of muscovy ducks, pekin ducks and their crossbreeds, and evaluation of heterosis effect. Arch. Tierz. Dummerstorf 47(3): 287299.

Wen-lin, J.I., Taizhou, and Jiangsu. 2009. Comparative study on the growth and development model of mule ducks and their patents. J. Anhui Agric. Sci. 37(25): 1202612030.

$\mathrm{Xu}$, Z.C. and J. Zhu. 1999. An approach for predicting heterosis based on an additive, dominance and additive xadditive model with environment interaction. J. Heredity. 82: 510-517. 